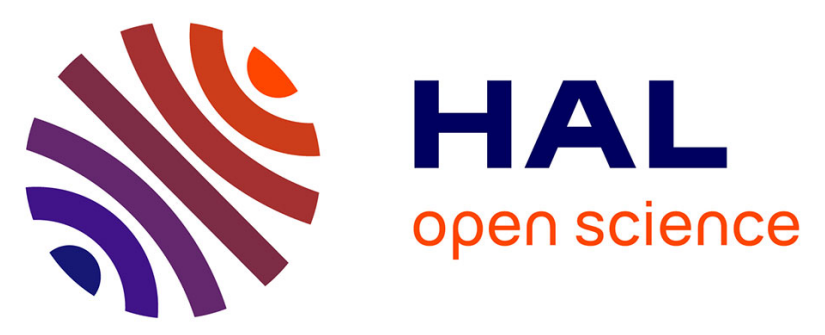

\title{
An exposure-based framework for grouping pollutants for a cumulative risk assessment approach: case study of indoor semi-volatile organic compounds.
} Kevin Fournier, Philippe Glorennec, Nathalie Bonvallot

\section{- To cite this version:}

Kevin Fournier, Philippe Glorennec, Nathalie Bonvallot. An exposure-based framework for grouping pollutants for a cumulative risk assessment approach: case study of indoor semi-volatile organic compounds.. Environmental Research, 2014, 130, pp.20-8. 10.1016/j.envres.2014.01.007 . hal-00982315

HAL Id: hal-00982315

https://hal-univ-rennes1.archives-ouvertes.fr/hal-00982315

Submitted on 16 Jun 2014

HAL is a multi-disciplinary open access archive for the deposit and dissemination of scientific research documents, whether they are published or not. The documents may come from teaching and research institutions in France or abroad, or from public or private research centers.
L'archive ouverte pluridisciplinaire HAL, est destinée au dépôt et à la diffusion de documents scientifiques de niveau recherche, publiés ou non, émanant des établissements d'enseignement et de recherche français ou étrangers, des laboratoires publics ou privés. 
An exposure-based framework for grouping pollutants for a cumulative risk assessment approach. Case study of indoor semi-volatile organic compounds.

FOURNIER KEVIN $(1,2)$, GLORENNEC PHILIPPE $(1,2)$, BONVALLOT NATHALIE $(1,2)$

(1) EHESP School of Public Health, Sorbonne Paris Cité, Avenue du Professeur Léon Bernard, 35043 Rennes Cedex, France

(2) INSERM UMR1085 IRSET (Research Institute in Environmental and Occupational Health), Rennes, France

\section{Corresponding author}

Nathalie Bonvallot

EHESP School of Public Health, Avenue du Professeur Léon Bernard, CS74312, 35043

Rennes Cedex, France. Tel: +332 990226 22. Fax: +332 990226 75. E-mail: nathalie.bonvallot@ehesp.fr

\section{Key-words}

Cumulative exposures, Risk Assessment, Toxicity Reference Values,Toxic Equivalent Factors, Hazard index

\section{Grant information}

We should like to thank the School of Public Health for funding. 


\begin{abstract}
:
Humans are exposed to a large number of contaminants, many of which may have similar health effects. This paper presents a framework for identifying pollutants to be included in a cumulative risk assessment approach. To account for the possibility of simultaneous exposure to chemicals with common toxic modes of action, the first step of the traditional risk assessment process, i.e. hazard identification, is structured in three sub-steps: 1a) Identification of pollutants people are exposed to, 1b) Identification of effects and mechanisms of action of these pollutants, 1c) Grouping of pollutants according to similarity of their mechanism of action and health effects. Based on this exposure-based grouping we can derive "multi-pollutant" toxicity reference values, in the "dose-response assessment" step. The approach proposed in this work is original in that it is based on real exposures instead of a limited number of pollutants from a unique chemical family, as traditionally performed. This framework is illustrated by the case study of semi-volatile organic compounds in French dwellings, providing insights into practical considerations regarding the accuracy of the available toxicological information. This case study illustrates the value of the exposure-based approach as opposed to the traditional cumulative framework, in whichchemicals with similar health effects were not always included in the same chemical class.
\end{abstract}




\section{Introduction}

Human beings use many chemicals in various circumstances, such as: manufacturing and use of products and articles, industrial processing, agriculture, etc. These chemicals and their byproducts are likely to be found in the environment and are the source of diffuse and multiple contaminations of the different compartments: pesticides in soils, water, diet or air, persistent organic pollutants in the food chain, urban air pollution, volatileand semi-volatile organic compounds in indoor and outdoor environments, etc. As a consequence, human beings areexposed throughoral, respiratory or dermal routesto a large variety of chemicalspresent in food, air, water and dust, generally at low doses. The presence of such pollutantsand their metabolites in human biological fluids has confirmed this hypothesis. For example, the National Health and Nutrition Examination Survey - designed to assess the health and nutritional status of adults and children in the United States - included biomonitoring surveysthat showed the presence of detectable levels of a large variety of chemicals and their metabolites in blood or urine of human people, such as metals, phthalates or pesticides' metabolites (NHANES, 2013).

Regulations related to the chemicals entering in European market, both for domestic and professional uses, are based on risk assessment and management (European Union, 2009, 2006). However, the laws on the use of chemicals (cosmetics, biocides, pesticides, medicines, food additives and more) do not allow a comprehensive and global risk analysis. Standard toxicological tools, in particular studies on laboratory mammals, are not suitable forstudying the effects induced by complex and low-dose chemical mixtures. Little knowledge is routinely generated on the hazards of these chemical mixtures. The real impact of dietary and environmentalcontamination is not known and therefore not fully taken into account in public health decisions. The implementation of cumulative risk assessment strategies for complex mixtures is therefore of high concern as statedby Sarigiannis and Hansen (Sarigiannis and Hansen, 2012).

Avariety ofcumulative risk assessment (CRA) methodologies have already been suggested to improve risk management decision-making. For example, toxic equivalent factors have been definedfor dioxins, furans, dioxin-like polychlorinated biphenyls (PCB-dl)andpolycyclic aromatic hydrocarbons (PAHs), on the basis of their ability to bind the Aryl hydrocarbon Receptor (Safe, 1990; Van den Berg et al., 2006, 1998). Similarly, the U.S. Environmental Protection Agencysuggestedusing an approach based onrelative potency factors(RPF) for organophosphate and carbamatepesticides on the basis oftheir ability to inhibit the acetylcholinesterase enzyme (US EPA, 2006, 2002). More recently, theseapproacheswere 
extended to other molecules, such as pyrethroid pesticides (Wolansky et al., 2005)and phthalates(Hannas et al., 2011). However, these approaches generally take into account only one chemical family. Taking into account pollutantsfrom different chemical familieswould undoubtedly better reflect actualenvironmental human exposures.This issue was first addressed by Kortenkamp and co-workerswho proposed a CRAbased on the anti-androgenic abilities of 15 substances including pesticides (fungicides, insecticides), as well asphthalates, brominated compounds and parabens(Kortenkamp and Faust, 2010). The hazard index method was then chosen to afford more flexibility in dealing with various data quality issues by using varying uncertainty factors. However, the use of different critical doses(no observed adverse effect level versus lowest observed adverse effect level for example)led to difficulties in the interpretation of results. In addition, this pioneeringstudy was based on the mechanism of toxicity of substances that people are not typicallyexposed to.It seems therefore necessary to pursue the improvement of the CRA methodology.

The objective of this work is to propose an additional step in theCRA approach, based on grouping pollutants people are actually exposed to. Only the threshold method will be developed (for non-carcinogenic or non-genotoxic compounds). We illustrate this exposurebased CRA framework with a case study based on exposure to Semi Volatile Organic Compounds (SVOCs) in French indoor environments.

\section{A brief review of cumulative risk assessment methods}

The risk assessment process was initially defined by the NRC in 1983 (National Research Council U.S. Committee on the Institutional Means for Assessment of Risks to Public 1983). In the traditional approach, four steps are used and described as follows: 1) Hazard identification, to determine whether a chemical is linked to one or morespecific health effects, 2) Dose-response assessment, to identify the relation between the magnitude of exposure and the likelihoodor occurrence of health effects in a population. In its simplest form, this step is the choice of a toxicity reference value (a reference dose for example)according to an exposure route and duration, 3) Exposure assessment, to determine the extent and the magnitude of human exposure, and 4) Risk characterization, to describe the nature and magnitude of human health risk, including uncertainties. This last step is the combination of the previous ones. It generally compares the estimated human exposure with the selected toxicity reference value. It results in a hazard quotient (Exposure / toxicity reference value) if the threshold assumption is used, or an excess risk (Exposure $x$ toxicity reference value) in the case of a non-threshold assumption. 
A dose-additivity assumption has been used for forty years (Sprague 1970)in the cumulative risk assessment process, where a threshold hypothesis is used. The simplest approach is to sum the hazard quotientobtained for each chemical (US EPA, 2000, 1986)to obtain a hazard index. The main limitation is the lack of comparability of the ratio obtained for each pollutant when, for example, the reference doses are not defined based on the same critical effect. This method could be used to identify the chemical of most concern in the mixture but cannotpredict the effect of the mixture. This method takes into account the most sensitive critical effect induced by each pollutant. The risk could be considered as negligiblewhen the hazard index is less thanone. If not, a more in-depth approach should be used. An improvement of this approach was proposedusingthe point of departure index which directly comparesthe exposure to a critical dose, or "point of departure", in which the same effect is selected for all substances, even if the point of departures are different:no observed adverse effect level, lowest observed adverse effect levelor benchmark dose). The point of departure indexis then compared to human exposure, leading to a margin of exposure that is interpretedkeeping in mind theuncertainties ofthe toxicological data used to derive the point of departure.Another approach is directly derived and extrapolatedfrom the toxic equivalent factor for dioxins, furans,PCB-dl and PAHs, based on their affinity to the arylhydrocarbon receptor. The RPF approach first described by the US EPA(US EPA, 2002)is based on the assumptions of a similar mechanism / mode of action and parallel dose-response curves. The toxic potency of each chemical is normalized relative to the best-known compound. These RPFs can be constructed by comparingthe toxicity indicators (benchmark doses based on the same mechanism for example, or an effective dose corresponding to a percentage of response or affinity). They are then used to weight the exposure of the different compounds, then added together to determine ahazard quotientbased on the toxicity reference valueof the index compound. This approach requires more accurate mechanistic information and can therefore be applied only to the most widely studied pollutants.Several reviews with a more in depth description of these approaches are available (Kortenkamp and Faust 2010; Sarigiannis and Hansen 2012).These CRA methodologies have been used in various contexts. For example, Wolansky and co-workers derived relative potency factors for 11 pyrethroids after an acute exposure in rats, based on the prolongation of the open state of sodium channels (Wolansky et al., 2005). Similarly, in 2002 and 2006, the US EPA proposed a CRA approach for 30 organophosphate pesticides based on brain cholinesterase inhibition in rats after exposure of 21 days or longerviaoral, dermal or respiratoryroutes. RPFs were determined according to their respectivebenchmark dose(US EPA, 2006, 2002).In 2011 the same approach was 
suggested to assess the risk related to exposure to a mixture of phthalates during pregnancy, based on a decrease in testosterone production and alteration of gene expression by fetal testes (Hannas et al., 2011).In 2013, Jensen and co-workerspublished a cumulative risk assessment for 4 anti-androgenic fungicides belonging to different chemical classes (triazoles, imidazoles, dicarboximides). They used the RPF approach based on benchmark dose calculation to assess two effects (increased gestation period in pregnant females and increased nipple retention in male offspring)(Jensen et al., 2013).

In the case of situations where toxicological data are complete, with a deeper understanding of mechanisms and modes of action, it is possible to refine CRA by using toxicokinetic interactions and internal doses at the target site of action (Haddad et al., 2001). Taking into account the toxicokinetic interactions was also developed by Sarigiannis and co-workers. they used a physiologically-based pharmacokinetic model to assess the internal dose of benzene following a co-exposure to four volatile organic compounds (benzene, toluene, ethylbenzene and xylene). These authors showed that benzene cancer risk estimate calculated from the combined exposure was lower than risk from benzene exposure alone. This was due to a metabolic competition (Sarigiannis and Gotti, 2008).

If these methods should be developed in the future, as it was suggested by the authors (Sarigiannis et al., 2009), these situations where mechanistic data are understood are unfortunately still too rare and it is not possible to develop this type of approach in all cases.

\section{An exposure-based conceptual framework}

\subsection{Initial assumptions}

\subsubsection{The concept of dose addition}

The concept of dose addition is a long-established concept suggested in the risk assessment process to take into account chemicals with a common mode of action, in which it is assumed that each component in the mixture acts as if it were a simple dilution of another one. The fundamental assumption is that each chemical in a mixture exhibits a common toxic mode of action. Typically, it would be necessary to know all toxicokinetic data and biochemical and molecular pathways for each compound in order to verify this concept. But biochemical interactions (absorption, compounds-cell interactions) cannot be known for all possible mixtures and all given situation, which is why a pragmatic approach was finally recommended for risk assessment. This concept is recommended for CRA processes by 
several organizations as a default approach for decision making when no data prove the contrary (European Commission, 2012; US EPA, 2010, 2002, 2000, 1986; WHO/IPCS, 2009), based on the fact that interactions between chemicals are unlikely to occur at environmentally relevant concentration(SCHER, 2007). The dose addition concept has also been observed for some mixtures. In 2008, Howdeshelland co-workersvalidated this concept for a mixture of five phthalate esters able to inhibit fetal testicular testosterone production in rats(Howdeshell et al., 2008). In 2009, other authors validated the same hypothesis, finding that the combined effects of a mixture of four anti-androgens from different chemical families were dose additive (for changes in ano-genital distance, retained nipples and sex organ weights). Nevertheless, they also observed synergistic effects on malformations of external sex organs (Christiansen et al., 2009). In 2012, Christen and co-workers showed that this dose-additivity concept is appropriate to assess themixture effect of antiandrogenic phthalates and bisphenol A(Christen et al., 2012). They also showed a tendency to synergism at high concentrations and antagonism at low concentrationsaccording to the model and the compound mixtures selected The authors explain thesedeviations from the dose-additivityby the mechanism of interaction at the androgen receptor (binding site and strength) rather than a toxicokinetic interaction. According to Evans and co-workers(Evans et al., 2012), these deviations can be explained by the type of chemical tested, the number of compounds in the mixture, and the design of the study. The authors designed experiments using mixtures of pollutants(plasticizers, phthalates, metals, PCBs, phytoestrogens, PAHs, heterocyclic amines, antioxidants, UV filters, musks, PBDEs and parabens) that address these factors. The first one was a "balanced" mixture with components present in proportion to a common effect concentration. The second one was a "non-balanced" mixture with components in proportion to potential human tissue concentrations. The second part of their study consistedof testing the individual and simultaneous ability of 16 potential modulator chemicals to influence the assay outcome produced by a reference mixture of chemicals. They concluded that the doseadditivity concept commonly provides a good prediction of mixture effects.

\subsubsection{Atrans-family multi-pollutant approach}

The selection of compounds is a critical step of in CRA. It would make sense to groupchemicals on the basis of chemical similarities because of dose additivity, but in real life situations, people are exposed toa variety of pollutants from different chemical families. This issue needs to be addressed,as pointed out by Sexton and Hattis in 2007 (Sexton and 
Hattis, 2007). In the framework we propose, the chemicals to be included in the CRA should not be limited to onechemical family (e.g. phthalates) or onechemical use (e.g. fungicides) but should be selected based on observed exposures or environmental contaminations.

\subsubsection{Data availability}

The risk assessment approach is currently used to address health risk policy issues related to environmental contaminants when epidemiological data are insufficient to establish causal relationships and calculate attributable risks to humans. The process has been defined by the US General Accounting Office as "a systematic, scientific description of potential adverse effects of exposures to hazardous substances or situations" and "a complex but valuable set of tools helping agencies to identify issues of potential concern, select regulatory options and estimate the range of a forthcoming regulation's benefit"(US GAO, 2001). Thus the main objective of a risk assessment approach is to assist policymakersin the decision-making process.Because the risk assessment process is implemented even if scientific data are lacking, a number of default assumptions are usually applied.A default option has been defined by the NRC as "the option chosen on the basis of risk assessment policy that appears to be the best choice in the absence of data to the contrary" (National Research Council, 1983). The main assumptions involve the value of using animal data to assess the risk in humans (same types of effects expected in both species), the use of a threshold approach for non-carcinogenic or non-genotoxic carcinogenic chemicals and the idea that humans are more vulnerable than laboratory animals. In the case of a CRA with a threshold approach, dose-additivity is also a default assumption. If new data becomes available, the default assumptions are not taken into account and the risk assessment process shouldbe more accurate leading to less conservative conclusions.

\subsection{Structuring the hazard identification of the CRA}

For a given situation, usingactualexposures for a CRArequiresa comprehensive view of pollutants, i.e.selecting pollutantsfrom a large variety. This isthe firstsub-step of hazard identificationin exposure-based CRA. In the second sub-step, the effects,modes and mechanisms of action of all the detected compounds are identified. In the last sub-step,the pollutants are grouped according to their similarity of action on the organism. At the end of these three sub-steps, the dose response assessment consists inderiving multi-pollutant toxicity reference values for each exposure situation, leading to the last two steps of the 
conventional approach, i.e. exposure assessment and risk characterization. The framework is presented in Table 1. Each of the 3 sub-steps is described below.

\subsubsection{Identification of pollutants people are exposed to}

This identification of pollutants people are exposed to can rely on human biological monitoring and/or on environmental monitoring. These data can originate from biomonitoring programs (NHANES, 2013; Schulz et al., 2007), from total diet studies(Arnich et al., 2012)orfrom environmental studies in general, indoor or particular environment (Lucas et al., 2012; Mompelat et al., 2011; Rudel and Perovich, 2010). Main limitations at this step are related to false negative (a pollutant is not identified although it should be). The presence of false negatives may be due to high limits of detection or by the transformation of the parent compoundinto unknown metabolites - in the environment or in the body.

\subsubsection{Identification of effects, modes and mechanisms of action}

From a biological point of view, an effect due to exposure to one or more pollutants is caused by a series of mechanisms of action or "key-events", defined by Boobisand co-workersas measurable events that are critical to the induction of the effect(Boobis et al., 2008, 2006)as shown in figure 1.On the basis ofthisstatement, several levels of effects can be defined:

- Clinical effect, which corresponds to an alteration of a body function observable by a clinical diagnosis. For example, alteration of cognitive or behavioral functions, such as hyperactivity or attention-deficit, could be diagnosed based on standardized testslike the Behavior Assessment Systems for Children;

- Impairment of the target organ. The clinical effect previously described is usually induced by an effect on an organ. For example, in the case of behavioral impairment, the effect on a target organ could be an alteration of the thyroid or the brain;

- Effect at a cellular level: at this scale, cell damage can cause alteration of the target organ. These effects can be observed directly in exposed laboratory animals (after autopsy, microscopicobservations) or by in vitro tests (cell cultures). Examples include swelling, necrosis or cell death, including changes in the dendritic morphology of hippocampal neurons or abnormal plasticity of the synaptic junctions.

- Effect at a molecular level, which corresponds to the direct interaction between the macromolecules responsible for cell function (proteins, aminoacids, lipids, nucleic acids) and the chemicals (or metabolites).A variety of intracellular mechanisms of 
action can be disrupted. These effects are observable by in vitro tests or with highthroughput techniques such as transcriptomics or proteomics.Examples include phosphorylation of the N-methyl-D-aspartate receptor or a direct interaction with the estrogenreceptors. These types of effects arerarelyelucidated. Nevertheless, the molecular consequences of these interactions can be identified, such as changes in Nmethyl-D-aspartate receptor expression, a decrease in neurotransmitters or enzymes levels (dopamine, etc.) or over-expression of a specific gene.In our framework, we consider the molecular consequence of direct interactions as an effect at a molecular level.

In this step, it is important to address the biological plausibility of the effects. The mode of action observed in animals mustbe plausible to humans and higher plausibility is associated with a higher confidence level(Meek \& Bucher, 2003).Thus, it is important to take into account the species tested (in vivo, in vitro), the window, route and duration of exposure, etc. Moreover, as pointed out by Borgert et al, a detailed characterization of the pharmacodynamics, pharmacokinetics and slope of dose response curves may be important criteria in evaluating whether the toxicity of a mixture can be predicted by the mode of action of its component chemicals (Borgert et al., 2004).

\subsubsection{Grouping pollutantsbased on similaraction}

The available information on effects, modes and mechanisms of action for each pollutant canbe gathered into a unique dendrogram recapitulating the 4 levels of effects (clinical, organic, cellular, and molecular). Figure 2 describes this framework that groups information according to theselevels. Pollutants inducing the same effects on organisms or having the same mechanism of action at a cellular and molecular level can be identified and grouped. This grouping is also a way to classify pollutants according to the availability of data. Itdrives the choice of a CRA method:hazard index, point of departure index, or RPF.According to the available information, the hazard indexor the point of departure indexapproachescan be used when we have information only on a clinical effect (e.g.reduced fertility, behavioral changes) or a target organ or cell, depending on the application of uncertainty factors (for each pollutant or for the mixture). When the mechanism of action is known (e.g. binding to a receptor) or the consequence of this mechanism of action is known (e.g. decreased protein synthesis), an RPF approachcan be used.

This exposure-based CRA framework was tested on a case study presented below. 


\section{Case study: semi-volatile organic compounds in French indoor environments}

\subsection{Context}

Semi-volatile organic compounds (SVOCs) such as phthalates, PBDEs and PCBs are ubiquitous in indoor environments because of the increasing use of new materials and substances (pesticides, plasticizers, flame retardants, preservatives) (Mercier et al, 2011)and most of them are considered as endocrine disruptors (Rudel and Perovich, 2010).Due to their physicochemical properties, SVOCs partition betweenair, airborne particles, surface and settled dust, making them easily bioaccessible, whether viarespiratory, oral or dermal routes. Children are particularly vulnerable to exposure (vulnerable biological systems and vulnerable behavior with hand-to-mouth activity).

\subsection{Step 1a: Pollutant identification based on real exposures}

A list of SVOCs was prioritized on the basis of their contamination and toxicity levels (Bonvallot et al, 2010). Nationwide sampling campaigns were carried out in French dwellingsto characterize the contamination of indoor air and settled dust by more than 55 SVOCs (Blanchard et al., 2011; Glorennec et al., 2011)measured together in a specific multiresidue analysis(Mercier et al., 2011; 2012). For CRA, we selected the SVOCswith concentrations in air or settled dust above the limit of quantificationin more than $25 \%$ of dwellings, on the basis of preliminary results $(n=235)$. We identified21 SVOCsout of 55 measured including 8 phthalates (di(2-ethylhexyl)phthalate (DEHP), dibutyl phthalate (DBP), di-isononyl-phthalate (DiNP), di-isobutyl-phthalate (DiBP), bentyl benzyl phthalate (BBP), di-ethyl phthalate (DEP), bis(2-methoxyethyl)phthalate (DMEP)anddi-methyl phthalate (DMP)), 4 PBDEs (BDE-47, -99, -100 and-209), 3 pesticides (lindane, permethrin and cypermethrin),3 PCBs (PCB-101, -138 and -153), 2 musks (galaxolide andtolanide) and bisphenol A (BPA).

\subsection{Step 1b: Hazard identification, effects and mechanisms of action}

Hazard identification of the 21 SVOCs was performed by means of a literature review focusing on two well-documented systems: the reproductive and nervous systems. Selection criteria included the description of mechanism of action of these SVOCs, and the description of the target organs/cells. When there were a great many articles, priority was given to the most recent ones.

\subsubsection{Reprotoxic effects}


According to the time of exposure (pre or post-natal), some SVOCs may induce malformations of the genital tract orreducedfertility (alteration of sperm production) in mammals due to their impact on Leydig and Sertoli cells. Different mechanismsof action have been suggested: inhibition of insulin-like 3(INSL3) synthesis; decreasedsteroidogenicenzyme levels (StAR, P450scc),leading to decreased testosterone synthesis;inhibition ofFollicle-Stimulating Hormone (FSH) action, leading to

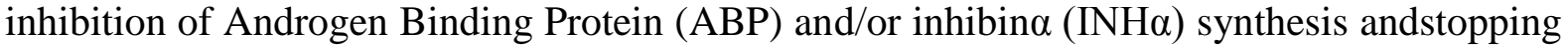
Sertoli cell proliferation;induction of ROS production, leading to the death of Sertoli cells; inhibition ofconnexin 43 (protein acting as a link between Sertoli and germ cells) with a release of Fas-L death signal. Reduced female fertility due to lower aromatase activity, and higher testosterone, androstenedione and progesterone secretionwas also observed (see Supplemental Material, figure 3).

\subsubsection{Neurotoxic effects}

Twelve of the 21 selected SVOCs act on the nervous system and are able to interfere with neuronal development (DEHP, BDE -47, -99, -209, BPA, PCB-101, -138, -153, lindane, permethrin and cypermethrin). Different modes of action were suggested: an increase in intracellular calcium which induces an increase of the frequency of the postsynaptic current and promotes the release of neurotransmitters;oxidative stress inducing neuronal apoptosis and a decrease in dopamine levels, inducingneurodegeneration. The selected SVOCs are also able to act on the thyroid in females and newborns,by inhibiting synthesis of T3 and T4 (thyroid hormones), which are strongly involved in the nervous system and brain development (see Supplemental Material, figure 4).

\subsection{Step 1c: Grouping pollutants}

Toxicologicaldatawere tabulated indendrogramsto visualize groups of pollutants according to their effects or mechanisms of action for each system (reproductive and nervous) (figures 3 and 4). This also showstheaccuracy of the available toxicologicalinformation (from target organ to molecular level).Five groups of pollutants were identified (Table 2)witha common molecular consequence of their mechanisms of action (decrease of testosterone synthesis, INSL3 or connexin 43 inhibition, decrease of T4 or dopamine levels). The data areaccurate enough to supporta hypothesis on the consequence of the molecular interaction between the SVOC and the organism. For these groups, aRPFapproach could be suggested. Most of these groups contain different chemical familiessuch as phthalates, pesticides, PCBs and PBDEs. 
Two other groups of pollutants described in Table 3 have common cellular or clinical effects (neuronal cell impairment and embryotoxic effects). The data are notaccurate enoughto elucidate the mechanism of action. For these groups, a Point of Departure Index could be suggested.

In all, considering indoor SVOCs and the reproductive and nervous systems, 7 groups of pollutants can be considered for a cumulative risk assessment: 5 groups for a RPF approach, and 2 for a point of departure index approach. They are composed of 5 to 12 pollutants from different chemical families in most cases.

\section{Discussion -Conclusion}

This framework adapted the traditional CRA approach to a trans-family multi-pollutant approach by taking into account data availability and actual exposures. Our proposed conceptual framework consists of adding a step to thetraditional cumulative risk assessment approach. Based on actual exposures, it groups pollutants according to their effect, on the basis of their mode or mechanism of action.Applying the concept to a real case allowed us to identify issues and to assess the value of the approach.

This approach involves a number of important methodological issues.First, selection of pollutantsmust be based on criteria of interest previously defined to achieve the objective (frequency of quantification in our case study). During this step, we eliminated a number of chemicals. Second, the available information varies according to the body system studied, since there is more mechanistic information onpollutants affecting reproduction than for other systems. The RPF approach wouldtherefore be easier to implement for reproductive effects. From a mechanistic point of view, the system for which there is the least information is the immune system. For this system, a point of departure indexapproach is likely to be promoted, emphasizing effects rather than mechanisms. The case study also illustrated that there is a trade-off between the number of pollutants we wish to consider and the accuracy level for dose-additivity. Indeed, because of the accuracy of available information, the more pollutants we want to include, the less likely it is that the RPF approach can be used. Third, uncertainty plays an important role in risk assessment. In the case of pollutants grouping for CRA approaches, the main sources of uncertainty include the selection of compounds (no pollutant must be neglected) and the knowledge of mechanisms or modes of action, which is fragmented. Nevertheless, the use of this approach provides a wider perspective on human health risks and results in a lower uncertainty than the traditional risk assessment. 
Finally, this case study demonstrated the value of an exposure-based CRA, as we determined that pollutants with similar effects or mechanisms of action donot all belong tothe same chemical family. The approach has also been shown to befeasiblealthough the greatest limitation is its dependence on the availability of toxicological data.

In conclusion, the proposed methodology for creating groups of substances with the same targets and modes or mechanisms of action can formthe basis for exposure-based cumulative risk assessment for many situations with complex exposures. The main challenge is still to generate toxicological - or epidemiological - data on the largest possible number of pollutants that are relevant to human exposure.

\section{Acknowledgments}

We would like to thank the FrenchSchool of Public Health (EHESP) and its LERES Laboratory for having provided SVOC contamination data.

\section{Competing financial interest declaration}

The authors declare they have no competing financial interests. 


\section{References}

Arnich, N., Sirot, V., Rivière, G., Jean, J., Noël, L., Guérin, T., Leblanc, J.-C., 2012. Dietary exposure to trace elements and health risk assessment in the 2nd French Total Diet Study. Food and chemical toxicology: an international journal published for the British Industrial Biological Research Association 50, 2432-49.

Blanchard, O., Glorennec, P., Mercier, F., Ramalho, O., Mandin, C., Bonvallot, N., 2011. Cumulative indoor exposures to Semi-Volatile Organic Compounds (SVOCs) in France: measurements of endocrine disruptors in 30 French dwellings, in: Indoor Air Conference.

Bonvallot, N, Mandin, C, Mercier, F, Le Bot, B, Glorennec, P, 2010. Health ranking of ingested semi-volatile organic compounds in house dust: an application to France. Indoor air $20,458-72$.

Boobis, A.R., Cohen, S.M., Dellarco, V., McGregor, D., Meek, M.E.B., Vickers, C., Willcocks, D., Farland, W., 2006. IPCS framework for analyzing the relevance of a cancer mode of action for humans. Critical reviews in toxicology 36, 781-92.

Boobis, A.R., Doe, J.E., Heinrich-Hirsch, B., Meek, M.E.B., Munn, S., Ruchirawat, M., Schlatter, J., Seed, J., Vickers, C., 2008. IPCS framework for analyzing the relevance of a noncancer mode of action for humans. Critical reviews in toxicology 38, 87-96.

Borgert, C.J., Quill, T.F., McCarty, L.S., Mason, A.M., 2004. Can mode of action predict mixture toxicity for risk assessment? Toxicology and applied pharmacology. 201(2), 85-96.

Christen, V., Crettaz, P., Oberli-Schrämmli, A., Fent, K., 2012. Antiandrogenic activity of phthalate mixtures: validity of concentration addition. Toxicology and applied pharmacology 259, 169-76.

Christiansen, S., Scholze, M., Dalgaard, M., Vinggaard, A.M., Axelstad, M., Kortenkamp, A., Hass, U., 2009. Synergistic disruption of external male sex organ development by a mixture of four antiandrogens. Environmental health perspectives 117, 1839-46.

European Commission, 2007. Opinion on risk assessment on indoor air quality. Scientific Committee on Health and Environmental Risks (SCHER).Directorate general for Health and Consumer Protection. 1-33.

European Commission, 2012. Toxicity and Assessment of Chemical Mixtures. Scientific Committees SCHER, SCENIHR, SCCS. Directorate general for Health and Consumers. 150.

European Union, 2006. Regulation (EC) No 1907/2006 of the European Parliament and of the Council of 18 December 2006 concerning the Registration, Evaluation, Authorisation and Restriction of Chemicals (REACH), establishing a European Chemicals Agency, amending 
Directive 1999/45/EC and repealing Council Regulation (EEC) No 793/93 and Commission Regulation (EC) No 1488/94 as well as Council Directive 76/769/EEC and Commission Directives 91/155/EEC, 93/67/EEC, 93/105/EC and 2000/21/EC. Available at http://eurlex.europa.eu

European Union, 2009. Regulation (EC) No 1107/2009 of the European Parliament and of the Council of 21 October 2009 concerning the placing of plant protection products on the market and repealing Council Directives 79/117/EEC and 91/414/EEC. Available at http://eur-lex.europa.eu

Evans, R.M., Scholze, M., Kortenkamp, A., 2012. Additive mixture effects of estrogenic chemicals in human cell-based assays can be influenced by inclusion of chemicals with differing effect profiles. PloS One 7, e43606.

Glorennec, P., Mercier, F., Blanchard, O., Bonvallot, N., Ramalho, O., Mandin, C., 2011. Cumulative indoor exposures to Semi-Volatile Organic Compounds (SVOCs)in France: the ECOS project, Indoor Air Conference Proceeding, Austin, TX, United States.Available at http://hal.inria.fr/docs/00/68/80/91/PDF/a509_4.pdf

Haddad,S., Béliveau,M., Tardif,R., Krishnan,K., 2001. PBPK modeling-based approach to account for interactions in the health risk assessment of chemical mixtures. Toxicological sciences 63,125-135.

Hannas, B.R., Lambright, C.S., Furr, J., Howdeshell, K.L., Wilson, V.S., Gray, L. E., 2011. Dose-response assessment of fetal testosterone production and gene expression levels in rat testes following in utero exposure to diethylhexyl phthalate, diisobutyl phthalate, diisoheptyl phthalate, and diisononyl phthalate. Toxicological sciences 123, 206-16.

Howdeshell, K.L., Wilson, V.S., Furr, J., Lambright, C.R., Rider, C. V, Blystone, C.R., Hotchkiss, A.K., Gray, L. E., 2008. A mixture of five phthalate esters inhibits fetal testicular testosterone production in the sprague-dawley rat in a cumulative, dose-additive manner. Toxicological sciences 105, 153-65.

Jensen, B.H., Petersen, A., Christiansen, S., Boberg, J., Axelstad, M., Herrmann, S.S., Poulsen, M.E., Hass, U., 2013. Probabilistic assessment of the cumulative dietary exposure of the population of Denmark to endocrine disrupting pesticides. Food and chemical toxicology 55C, 113-120.

Kortenkamp, A, Faust, M., 2010. Combined exposures to anti-androgenic chemicals: steps towards cumulative risk assessment. International journal of andrology 33, 463-74. 
Lucas, J.-P., Le Bot, B., Glorennec, P., Etchevers, A., Bretin, P., Douay, F., Sébille, V., Bellanger, L., Mandin, C., 2012. Lead contamination in French children's homes and environment. Environmental research 116, 58-65.

Meek, M., Bucher, J., 2003. A framework for human relevance analysis of information on carcinogenic modes of action. Critical reviews in toxicology 33, 591-653.

Mercier, F., Glorennec, P., Derbez, M., Thomas, O., Le Bot, B., 2011. Cumulative indoor exposures to Semi-Volatile Organic Compounds in France: measurement methods in settled dust, in: Indoor Air Conference, Austin, TX, United States.

Mercier, F., Glorennec, P., Blanchard, O., Le Bot, B., 2012. Analysis of semi-volatile organic compounds in indoor suspended particulate matter by thermal desorption coupled with gas chromatography/mass spectrometry. Journal of chromatography. A 1254, 107-14.

Mercier, F., Glorennec, P., Thomas, O., Le Bot, B., 2011. Organic contamination of settled house dust, a review for exposure assessment purposes. Environmental science \& technology $45,6716-27$.

Mompelat, S., Thomas, O, Le Bot, B, 2011. Contamination levels of human pharmaceutical compounds in French surface and drinking water. Journal of environmental monitoring 13, 2929-39.

National Research Council, 1983. Risk assessment in the federal government: managing the process.U.S. Committee on the Institutional Means for Assessment of Risks to Public Health, Commission on Life Sciences. National Academy Press, Washington D.C.

NHANES, 2013. Fourth National Report on Human Exposure to Environmental Chemicals. Updated tables, September 2013. US Department of Health and Human and Service. Center for Disease Control and Prevention.

Rudel, R.A., Perovich, L.J., 2010. Endocrine disrupting chemicals in indoor and outdoor air. Atmospheric environment 43, 170-181.

Safe, S, 1990. Polychlorinated biphenyls (PCBs), dibenzo-p-dioxins (PCDDs), dibenzofurans (PCDFs), and related compounds: environmental and mechanistic considerations which support the development of toxic equivalency factors (TEFs). Critical reviews in toxicology $21,51-88$.

Sarigiannis, D., Hansen, U., 2012. Considering the cumulative risk of mixtures of chemicals a challenge for policy makers. Environmental health 11 Suppl 1, S18.

Sarigiannis, D., Gotti, A., Cimino Real, G., Marafante, E., 2009. Reflections on new directions for risk assessment of environmental chemical mixtures. International journal of risk assessment and Management 13(3/4), 216-241. 
Sarigiannis, D.A., Gotti, A., 2008. Biology-based dose-response models for health risk assessment of chemical mixtures. Fresenius environmental bulletin 17, 1439-1451.

Schulz, C., Conrad, A., Becker, K., Kolossa-Gehring, M., Seiwert, M., Seifert, B., 2007. Twenty years of the German Environmental Survey (GerES): human biomonitoring-temporal and spatial (West Germany/East Germany) differences in population exposure. International journal of hygiene and environmental health 210, 271-97.

Sexton, K., Hattis, D., 2007. Assessing cumulative health risks from exposure to environmental mixtures - three fundamental questions. Environmental health perspectives $115,825-32$.

Sprague, J.B., 1970. Measurement of pollutant toxicity to fish. II. Utilizing and applying bioassay results. Water research 4, 3-32.

US EPA, 1986. Guidelines for the Health Risk Assessment of Chemical Mixtures.

US EPA, 2000. Supplementary Guidance for Conducting Health Risk Assessment of Chemical Mixtures.

US EPA, 2002. Guidance on Cumulative Risk Assessment of Pesticide Chemicals That Have a Common Mechanism of Toxicity. Office of Pesticide Programs.

US EPA, 2006. Organophosphorus Cumulative Risk Assessment - 2006 Update. Office of pesticide Programs.

US EPA, 2010. Development of a relative potency factor (RPF) approach for polycyclic aromatic hydrocarbon (PAH) mixtures. In support of Summary Information on the Integrated Risk Information System (IRIS).

US GAO, 2001. Report to Congressional Requesters. Chemical Risk Assessment, selected federal agencies' procedures, assumptions, and policies. GAO 01810. 1-234.

Van den Berg, M., Birnbaum, L., Bosveld, T., Brunström, B., Cook, P., Feeley, M, Giesy, J.P., Hanberg, A, Hasegawa, R., Kennedy, S.W., Kubiak, T., Larsen, J.C., Van Leeuwen, F.X., Liem, a K., Nolt, C., Peterson, R E, Poellinger, L., Safe, S, Schrenk, D, Tillitt, D., Tysklind, M, Younes, M., Waern, F., Zacharewski, T., 1998. Toxic equivalency factors (TEFs) for PCBs, PCDDs, PCDFs for humans and wildlife. Environmental health perspectives 106, 775-92.

Van den Berg, M., Birnbaum, L.S., Denison, M., De Vito, M., Farland, W., Feeley, Mark, Fiedler, H., Hakansson, H., Hanberg, Annika, Haws, L., Rose, M., Safe, Stephen, Schrenk, Dieter, Tohyama, C., Tritscher, A., Tuomisto, J., Tysklind, Mats, Walker, N., Peterson, Richard E, 2006. The 2005 World Health Organization reevaluation of human and 
Mammalian toxic equivalency factors for dioxins and dioxin-like compounds. Toxicological sciences 93, 223-41.

WHO/IPCS, 2009. Assessment of combined exposures to multiple chemicals: report of a WHO/IPCS international workshop on aggregate/cumulative risk assessment. Geneva.

Wolansky, M.J., Gennings, C., Crofton, K.M., 2005. Relative potencies for acute effects of pyrethroids on motor function in rats. Toxicological sciences 89, 271-7. 
Table 1:Comparison of the proposed exposure-based cumulative risk assessment framework with the conventional cumulative risk assessment.

\begin{tabular}{|c|c|}
\hline Conventional CRA approach & Exposure-based CRA approach \\
\hline \multirow{3}{*}{ 1. Hazard identification } & $\begin{array}{l}\text { 1a. Identification of pollutants people are } \\
\text { exposed to }\end{array}$ \\
\hline & $\begin{array}{l}\text { 1b. Hazard identification: effects and } \\
\text { mechanisms of action of each pollutant }\end{array}$ \\
\hline & $\begin{array}{l}\text { 1c. Grouping of pollutants with similar } \\
\text { effects and/or mechanisms of action }\end{array}$ \\
\hline 2. Selection of toxicity reference values & $\begin{array}{l}\text { 2. Derivation of "multi-pollutant"toxicity } \\
\text { reference values }\end{array}$ \\
\hline \multicolumn{2}{|c|}{ 3. Exposure assessment } \\
\hline \multicolumn{2}{|c|}{ 4. Risk characterization } \\
\hline
\end{tabular}


Table 2: Groups of semi volatile organic compounds (SVOCs)for which the relative potency approach is suggested

\begin{tabular}{|c|c|c|c|c|}
\hline $\begin{array}{l}\text { Groups } \\
\text { of } \\
\text { SVOCs }\end{array}$ & Description & Clinical effects & $\begin{array}{l}\text { Cellular } \\
\text { effects }\end{array}$ & Mechanisms \\
\hline Group A & $\begin{array}{l}\text { DEHP, DiNP, DiBP, } \\
\text { BBP, DEP, BDE 47, BDE } \\
\text { 99, BDE 100, } \\
\text { BPA,lindane,permethrin, } \\
\text { cypermethrin }\end{array}$ & $\begin{array}{l}\text { Reproduction impairment: } \\
\text { Depending on the window } \\
\text { of exposure: decrease in } \\
\text { sperm quality or } \\
\text { hypospadias }\end{array}$ & $\begin{array}{l}\text { Leydig cell } \\
\text { impairment }\end{array}$ & $\begin{array}{l}\text { Decrease of } \\
\text { testosterone } \\
\text { synthesis by } \\
\text { decrease of } \\
\text { steroidogenic } \\
\text { enzymes levels }\end{array}$ \\
\hline Group B & $\begin{array}{c}\text { DEHP, DBP, DiNP, } \\
\text { DiBP, BBP }\end{array}$ & $\begin{array}{l}\text { Reproduction impairment: } \\
\text { Cryptorchodism only if } \\
\text { prenatal exposure }\end{array}$ & $\begin{array}{l}\text { Leydig cell } \\
\text { impairment }\end{array}$ & INSL3 inhibition \\
\hline Group C & $\begin{array}{c}\text { DEHP, DBP, DiNP, } \\
\text { DiBP, BBP, BPA, } \\
\text { lindane, dieldrin }\end{array}$ & $\begin{array}{l}\text { Reproduction impairment: } \\
\text { Decrease in sperm quality }\end{array}$ & $\begin{array}{l}\text { Sertoli and } \\
\text { germ cell } \\
\text { detachment }\end{array}$ & $\begin{array}{c}\text { Connexin } 43 \\
\text { inhibition }\end{array}$ \\
\hline Group D & $\begin{array}{c}\text { BDE 47, BDE 99, BDE } \\
\text { 209, BPA, PCB 101, PCB } \\
\text { 153, lindane, permethrin, } \\
\text { cypermethrin }\end{array}$ & $\begin{array}{l}\text { Nervous system: } \\
\text { possible } \\
\text { neurodegeneration }\end{array}$ & $\begin{array}{l}\text { Thyrocyte } \\
\text { cell } \\
\text { impairment }\end{array}$ & $\begin{array}{c}\text { Decrease of } \\
\text { thyroxine (T4) } \\
\text { levels }\end{array}$ \\
\hline Group E & $\begin{array}{c}\text { BPA, PCB 101, PCB 153, } \\
\text { lindane, permethrin, } \\
\text { cypermethrin }\end{array}$ & $\begin{array}{l}\text { Nervous system: } \\
\text { possible } \\
\text { neurodegeneration }\end{array}$ & $\begin{array}{l}\text { Neuronal } \\
\text { cell } \\
\text { impairment }\end{array}$ & $\begin{array}{c}\text { Decrease of } \\
\text { dopamine levels }\end{array}$ \\
\hline
\end{tabular}


Table 3: Groups of semi volatile organic compounds (SVOCs)for which the point of departure indexapproach is suggested

\begin{tabular}{|c|c|c|c|c|}
\hline $\begin{array}{l}\text { Group of } \\
\text { SVOCs }\end{array}$ & Description & Clinical effects & $\begin{array}{l}\text { Cellular } \\
\text { effects }\end{array}$ & Mechanisms \\
\hline Group F & $\begin{array}{c}\text { BDE 47, BDE 99, BDE } \\
\text { 100, BDE 209, BPA, PCB } \\
\text { 101, PCB 138, PCB 153, } \\
\text { lindane, permethrin, } \\
\text { cypermethrin }\end{array}$ & $\begin{array}{l}\text { Nervous system: } \\
\text { Neurodegeneration }\end{array}$ & $\begin{array}{l}\text { Neuronal } \\
\text { cell } \\
\text { impairment }\end{array}$ & $?$ \\
\hline Group G & $\begin{array}{c}\text { DEHP, DBP, DMEP, } \\
\text { BPA,lindane }\end{array}$ & $\begin{array}{c}\text { Reproduction: } \\
\text { Embryotoxic, fetotoxic } \\
\text { and/or teratogenic } \\
\text { effects }\end{array}$ & $?$ & $?$ \\
\hline
\end{tabular}


Figure 1: Effect of pollutants at different body scales

We are exposed, via different routes, to a number of pollutants which penetrate the body and reach the cells of target tissues and organs. Key molecular events are responsible for organic dysfunction affecting the exposed population.

\section{CHEMICAL / ORGANISM INTERACTION}

\begin{tabular}{|c|}
$\begin{array}{c}\text { EXPOSURE }= \\
\text { External dose } \\
\text { oral, respiratory, } \\
\text { dermal }\end{array}$ \\
circulates in the blood \\
Quantity that enters \\
the organism \\
Generally what \\
Internal dose $=$
\end{tabular}


Figure 2: Suggested way of presenting toxicologicalinformation in a cumulative risk $\underline{\text { assessment }}$

Traditionally, the hazard index approach is used to assess the health risk of a substance. The point of departure index approach is used when more accurate information (physiological effect, target organ or target cells) is available. The Relative Potency Factor (RPF) approach is used when even more accurate information (mode or mechanism of action) is available.

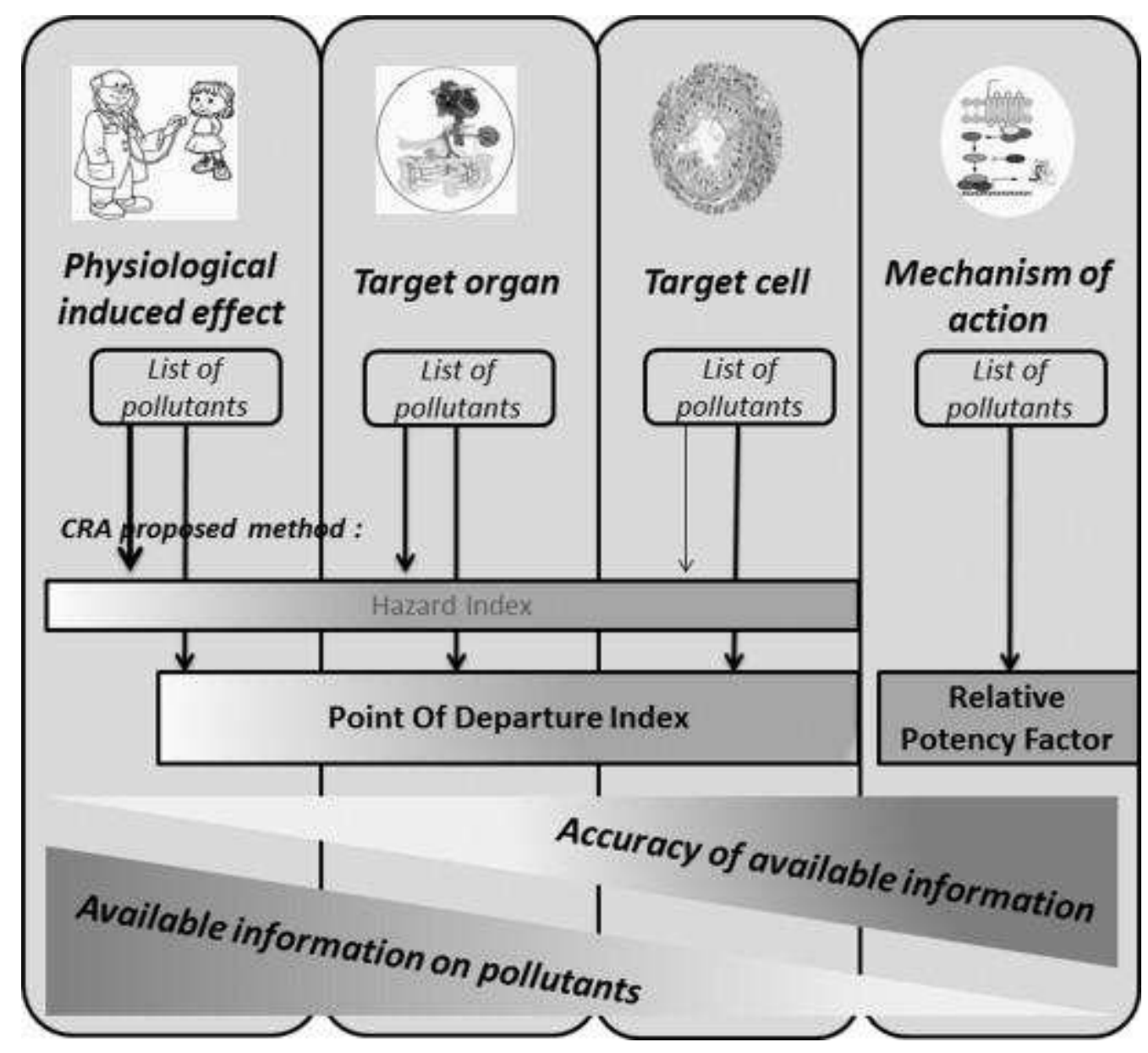


Figure 3: Mechanisms of action and toxic effects of selected indoor semi volatile organic compounds (SVOCs)on the reproductive system

15 pollutants act at different levels of the reproductive system. This dendrogramshowsthe accuracy of the information for each one.It allows us to identifythose acting together at different scales of this system, which can be grouped to determine toxicityreference values.

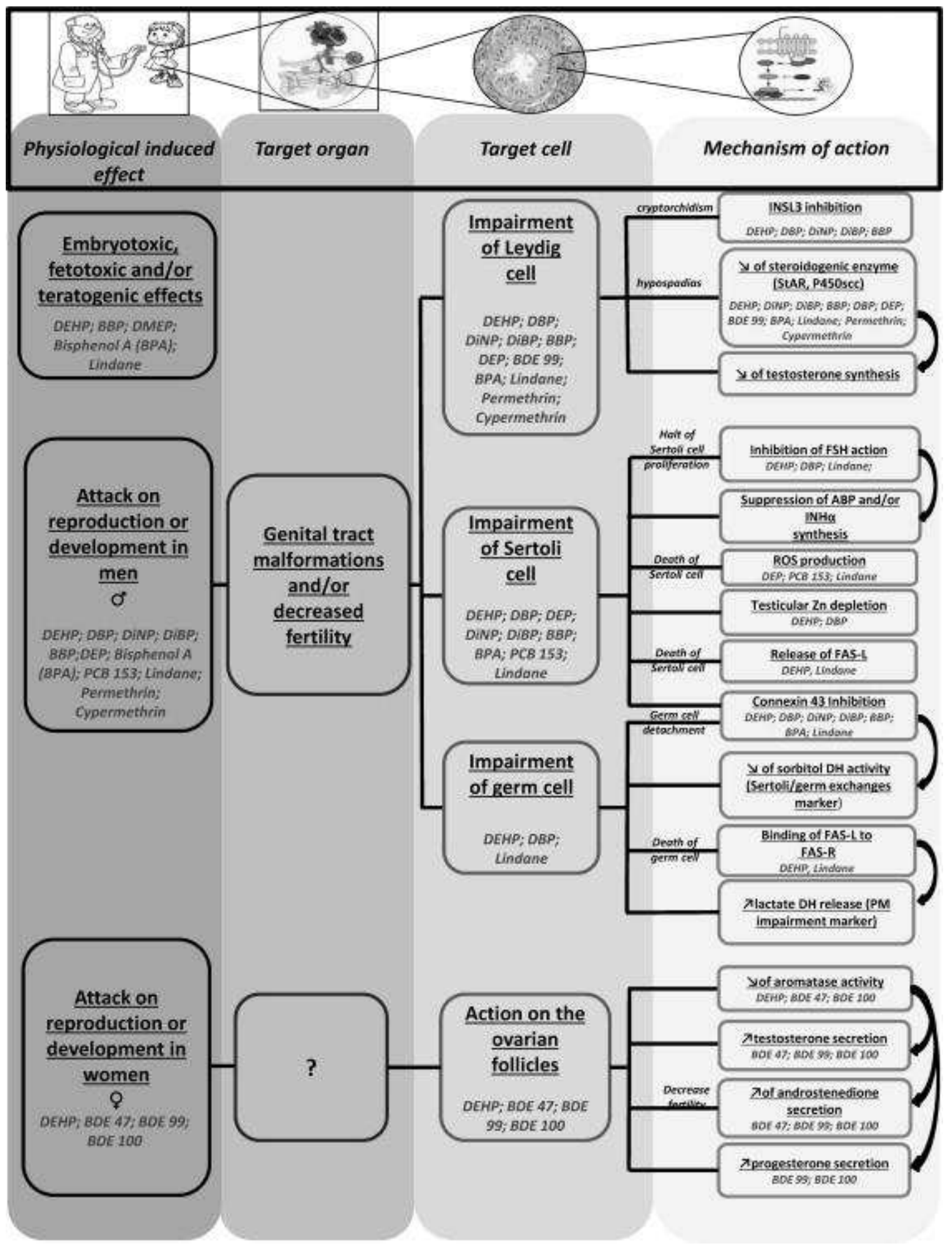


Figure 4: Mechanisms of action and toxic effects of selected indoor semi volatile organic compounds(SVOCs) on the nervous system

12 pollutants act at different levels of the nervous system. This dendrogramshowsthe accuracy of the information for each one. It allows us to identify those acting together at different scales of this system, which can be grouped to determine toxicityreference values.

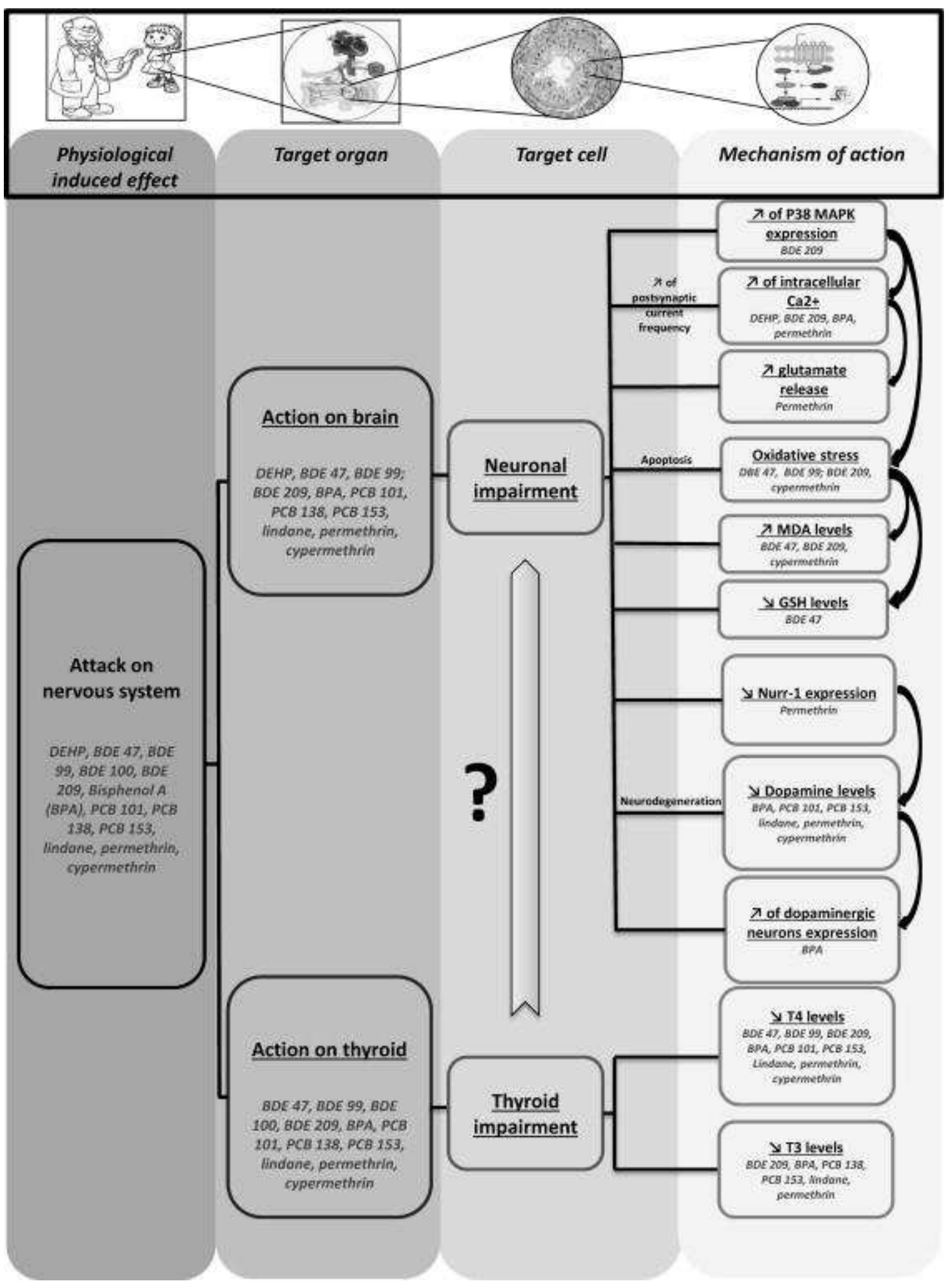

